\title{
MEWASPADAI VIRUS LGBT PADA PENDIDIKAN \\ ANAK
}

\author{
Hikmatur Rahmah
}

\section{Abstract}

LGBT (Ledian, Gay, Bisexual and Transgender) is a frightening epidemic of socidy, espeially in Indonesia. The eqidenic also infets most dildren and addescents. So as eduratas, both parents and teaches shoild pay partiailar attention to the symptoms that cause vins LGBT in the commuity, espeeially in dildren's edration Because it is against the nature noms, astans, reigion and morals of humanity. Marever, LGBT's behavior is not a disese transmitted through genes or disades, but more to the consequences mistakes and eros of dildren's eduration

\section{Abstrak}

LG BT (Lesbian, Gay, Biseksual dan Transgender) adalah epidemi menakutkan dalam masyarakat, terutama di Indonesia. Penyakit ini menginfeksi sebagian besar anak-anak dan remaja. Jadi sebagai pendidik, baik orang tua dan guru harus memberikan perhatian khusus pada gejala-gejala yang menyebabkan virus LGBT di masyarakat, terutama dalam pendidikan anak-anak. Karena itu bertentangan dengan sifat, norma, adat istiadat, agama dan moral kemanusiaan. Terlebih lagi, perilaku LG BT bukanlah penyakit yang ditularkan melalui gen atau gangguan, tetapi lebih kepada konsekuensi kesalahan dan erosi pendidikan anak-anak.

Keyword : LGBT, eetration dildren 


\section{PEN DAHULUAN}

Berbicara mengenai LGBT (Lesbi, Gay, Biseksual dan Transgender) ialah berbicara mengenai sebuah fenomena kehidupan yang menyimpang dari diri seorang manusia yang sehat. $D$ an ini menjadi penting untuk dikaji, dikarenakan LG BT ini ibarat virus yang menyebar dan menular cepat di masyarakat. Sehingga angka pengidap LGBT di Indonesia terus meningkat dari tahun ke tahun.

Kelompok masyarakat LGBT sendiri belum mendapat tempat di Indonesia. Banyak masyarakat yang berpandangan negatif, merasa jijik, benci dan mengucilkan kelompok LGBT. Yang mana ini merupakan fenomena yang aktual dan semakin ramai menjadi perbincangan yang negatif dalam masyarakat. Aktivitas dan perkembangan LGBT semakin hari meningkat yang sangat mengkhawatirkan. Sebab perkembangan LGBT akan memberikan pengaruh negatif yang sangat signifikan bagi pertumbuhan dan perkembangan anak dan remaja khususnya.

Sikap anak dan remaja baik laki-laki maupun perempuan sangat mudah mencontoh pada hal-hal yang dia

nggap trend atau gaya hidup maju. Apalagi budaya LG BT yang pada awal perkembangannya telah tumbuh dan berkembang pada negara maju seperti Amerika. Maka meniru budaya Amerika bagi remaja adalah sebuah trend atau gaya hidup yang memberikan kebanggaan tersendiri bagi mereka. Tetapi anak-anak, remaja dan bahkan orang dewasa sendiri kurang menyadari bahaya dan akibat dari perilaku LGBT, baik dari sisi agama, kesehatan dan sosial.

Hal ni sendiri terjadi karena masa-masa remaja adalah waktu dimana seseorang mencari jati diri dan lebih sering meniru apa yang mereka lihat dilingkungannya. Maka, apabila tidak didampingi dengan baik anak dalam usia dibawah 18 tahun akan sangat rentan terjerumus kepada orientasi seks menyimpang. 
Melihat fakta tersebut, tentu sudah seharusnya masyarakat melek terhadap permasalahan seks menyimpang dengan berbekal pengetahuan pendidikan seks, serta melakukan proteksi terhadap anak maupun anggota keluarga lainnya agar tidak terjerumus kedalam tindakan LG BT.

Begitupula halnya dengan penderita perilaku LG BT sudah sepatutnya mendapat rehabilitasi agar dapat kembali menjadi normal. Karena LGBT merupakan penyakit yang dapat disembuhkam melalui rehabilitasi rutin. Apabila hal seperti itu tidak diterapkan maka dikhawatirkan LGBT ini akan terus menyebar di masyarakat. Sehingga generasi penerus Bangsa akan terus mengalami kerusakan moral gara-gara perilaku seks menyimpang ini. ${ }^{1}$

Dalam agama Islam sendiri, LGBT termasuk dalam kategori dosa besar. Larangan untuk melakukan perilaku LGBT terdapat dalam Al-Q ur'an maupun hadis. LGBT juga merupakan pelanggaran terhadap fitrah mengakibatkan apa yang diistilahkan dengan 'uqubatul fitrah (sanksi fitrah). D alam konteks pelanggaran terhadap fitrah seksual, sanksinya antara lain apa yang dikenal dengan penyakit AID S.

\section{Konsep Seksualitas}

Menurut Sigmund Freud, ${ }^{2}$ bahwa kebutuhan seksual adalah kebutuhan vital pada manusia. Jika tidak terpenuhi kebutuhan ini akan mendatangkan gangguan kejiwaan dalam bentuk tindakan abnormal. Artinya bahwa kebutuhan seksual sebagai salah satu kebutuhan yang timbul dari dorongan nafsu untuk mencapai kepuasan jasmani dan kepuasan batin juga dapat timbul dari dorongan mempertahankan keturunan.

\footnotetext{
${ }^{1}$ https://www.jawapos.com/read/2017/12/24/177083/lgbt-makin-marak-dikalangan-anak-pakar-al-azhar-sarankan-ini, (11 April 2018).

${ }^{2}$ Yatimin, Etika Seksual dan Penyimpangannya dalam Islam, (Jakarta: Amzah,2003), 54.
} 
Seksualitas dalam arti yang luas ialah semua aspek badaniah, psikologi dan kebudayaan yang berhubungan langsung dengan seks dan hubungan seks manusia. Untuk mengerti seksualitas manusia, baik normal ataupun abnormal, perlu dimiliki latar belakang bukan saja psikiatri dan perilaku, tetapi juga anatomi seksual. Harus diketahui pula apa yang sebenarnya dilakukan manusia dalam hal seks, apa yang telah dilakukan dan apa saja yang hendak dilakukan, agar dengan demikian dapat diketahui prasangka sendiri tentang hal ini sehingga dapat dibetulkannya. ${ }^{3}$

\section{Seksualitas Nomal}

Menurut Maramis, ${ }^{4}$ Perilaku seksual yang normal ialah dapat menyesuaikan diri bukan saja dengan tuntutan masyarakat, tetapi juga dengan kebutuhan individu mengenai kebahagiaan dan pertumbuhan, yaitu perwujudan diri sendiri atau peningkatan kemampuan individu untuk mengembangkan kepribadiannya menjadi lebih baik.

Penyesuaian diri seksual yang sehat adalah kemampuan memperoleh pengalaman seksual tanpa rasa takut dan salah, jatuh cinta pada waktu yang cocok dan menikah dengan pasangan yang dipilihnya serta mempertahankan rasa cinta kasih dan daya tarik seksual terhadap pasangannya. Pasangannya itu tidak mempunyai gangguan atau kesukaran yang serius yang dapat mengganggu, merusak atau meniadakan suatu hubungan bahagia. ${ }^{5}$

\section{SeksualitasAbnomal}

Berbicara mengenai tindakan abnormal pasti berhadapan dengan masalah yang menyangkut tingkah laku normal dan tidak normal. G aris pemisah tingkah laku normal dan tidak normal selalu tidak jelas. Para ahli psikologi mengalami kesulitan untuk membedakan apa yang dimaksud tingkah laku normal dan abnormal.

\footnotetext{
${ }^{3}$ Maramis W. F., Catatan IImu Kedokteran Jiwa, , (Surabaya: Airlangga University Press 2004), 300.

${ }^{4} \mathrm{Ibid}$.

${ }^{5}$ Ibid.300-301.
} 
Menurut Linda de Clerq, ${ }^{6}$ dilihat dari sudut pandang ilmu psikologi pendidikan yang dimaksud dengan tingkah laku abnormal ialah tingkah laku yang menyimpang dari norma-norma tertentu dan dirasa mengganggu orang lain.

Sarlito Wirawan sebagaimana yang dikutip oleh Yatimin, ${ }^{7}$ membagi penyimpangan seksual kepada dua jenis:

a. Perilaku penyimpangan seksual karena kelainan pada objek. Pada penyimpangan ini dorongan seksual yang dijadikan sasaran pemuasan lain dari biasanya. Pada manusia normal, objek tingkah laku seksual ialah pasangan dari lawan jenisnya, tetapi pada penderita penyimpangan seksual objeknya bisa berupa orang dari jenis kelamin yang berbeda, melakukan hubungan seksual dengan hewan, dengan mayat, sodomi, oral seksual, homoseksual, lesbian, dan pedhophilia.

b. Perilaku penyimpangan etika seksual karena kelainan pada caranya. Pada penyimpangan seksual jenis ini dorongan seksual yang dijadikan sasaran pemuasan seksual tetap lawan jenis, tapi caranya berbeda dengan norma-norma susila dan etika. Yang termasuk perilaku penyimpangan etika seksual adalah perzinahan, perkosaan, hubungan seks dengan saudaranya sendiri, melacur dan sejenisnya.

\section{Definisi LGBT}

LGBT merupakan singkatan dari Lesbian, Gay, Bisexual and Transgender adalah istilah yang digunakan padaawal tahun '90an sampaisekarang, LGBT diambil dari singkatan LGB yang awal mulanya digunakan sebagai pengganti ungkapan 'gry commmity (komunitas gay). ${ }^{8}$

\footnotetext{
${ }^{6}$ Yatimin, Etika Seksual dan Penyimpangannya dalam Islam, (Jakarta: Amzah,2003), 54. 
D ewasa ini istilah LGBT dipakai seseorang atau siapapun yang mempunyai perbedaan orientasi seksual dan identitas gender berdasarkan kultur tradisional, yaitu heteroseksial. Lebih mudahnya, orang yang mempunyai orientasi seksual dan identitas non-heteroseksual seperti homoseksual, biseksual atau yang lain dapat disebut LG BT ${ }^{9}$

Lesbian berasal dari kata Lesbos yaitu pulau di tengah lautan Egis yang pada zaman kuno dihuni oleh para wanita. Menurut mitologi Yunani, hubungan percintaan sejenis terjadi di pulau itu antara putri Shappo dan Athis. ${ }^{10}$ Kamus Besar Bahasa Indonesia $^{11}$ mengidentifikasikan Lesbian sebagai wanita yang mencintai atau merasakan rangasangan seksual sesama jenisnya. Sedangkan Heru Kasida Brataatmaja ${ }^{12}$ mengidentifikasikannya sebagai sebadan sesama jenis (kelamin) atau cinta sesama jenis (wanita). Kamus Bahasa Melayu Nusantara memberikan pengertian lesbian sebagai perempuan yang mengadakan hubungan seks atau cinta birahi sesama perempuan. Menurut Ali Chasan Umar, ${ }^{13}$ lesbian adalah berupa perbuatan menggesekkan atau menyentuhkan alat vital saja dan bukannya ejakulasi.

Pada kaum wanita terdapat dua kelompok homoseksualitas. Kelompok pertama ialah wanita yang menujukkan banyak ciri-ciri kelaki-lakian, baik dalam susunan jasmani dan tingkah lakunya. Maupun pada pemilihan objek erotiknya. Kelompok yang kedua ialah mereka yang tidak memiliki tanda-tanda kelainan fisik. ${ }^{14}$

Secara gramatikal, tidak ada perbedaan penggunaan kata antara homoseksual dan lesbian. D alam bahasa Arab kedua-duanya dinamakan al-liwath Pelakunya dinamakan al-luthy. Namun menurut

\footnotetext{
${ }^{9}$ Ibid

${ }^{10}$ Kartini Kartono, Psikologi Abnormal dan Abnormalitas Seksual, (Bandung: CV. Mandar Maju, 1989), 249.

${ }^{11}$ Kamus Besar Bahasa Indonesia, (Jakarta: Balai Pustaka, 2002),665.

${ }^{12}$ Heru Kasida Brataatmaja, Kamus Bahasa Indonesia, (Yogyakarta.Penerbit Kanisius, 1994) 156.

${ }^{13}$ Akhmad Azhar Abu Miqdad, 85.

${ }^{14}$ Kartini Kartono, Psikologi Abnormal dan Abnormalitas Seksual, (Bandung: CV. Mandar Maju, 1989), 265.
} 
Imam al-Mawardi menyebut homoseksual dengan livath dan lesbian dengan sihaq atau msaahaqah ${ }^{15}$

Al-Livath menurut pandangan al-Mawardi adalah perilaku seksual antara laki-laki atau lebih dikenal dengan istilah homoseksual. Pengertian homoseksual ini sama dengan istilah Musaahaqah atau lesbian. Tetapi lesbian lebih kepada hubungan seksual antara perempuan dengan perempuan.

Perilaku tersebut tidak hanya terbatas berhubungan seksual, tetapi gejala-gejala yang menunjukkankearah perbuatan ini disebut juga seorang lesbian atau homoseksual, misalnya menyukai atau mencintai dengan sesama jenis kelamin, berpacaran dan bahkan berhubungan seksual.

D alam kamus besar bahasa Indonesia ${ }^{16}$, homoseksual yaitu hubungan seks dengan pasangan sejenis (pria dengan pria). Menurut Soejono Soekanto, homoseksual ${ }^{17}$ juga diartikan sebaga orang yang mengalami ketertarikan emosional, seksual atau rasa sayang terhadap sejenis, sedangkan biseksual merasa nyaman melakukan hubungan seksual dengan kedua jenis kelamin kelamin.

Secara sosiologis, homoseksual merupakan seseorang yang cenderung mengutamakan orang sejenis kelaminnya sebagai mitra seksual. Homoseksualitas merupakan kecenderungan untuk tertarik kepada orang lain yang sejenis. Homoseksualpun diartikan sebagai sikap-tindak perilaku para homoseksual.

Homoseksual sebagaimana menurut pengertian pendapatpendapat di atas adalah suatu perilaku seks antara laki-laki dengan laki-laki atau antara sesama jenis laki-laki. Seorang laki-laki yang memiliki perilaku seks homoseksual hanya menyukai dan mencintai, mendekati, dan bahkan berhubungan kelamin dengan sesama jenisnya saja yaitu hanya kepada laki-laki. Sebaliknya laki-

${ }^{15}$ M uhammad Mahmud Nasution, Fenomena LBGT Dalam Perspektif Hukum Islam, (Jurnal al-M aqasid Volume 2 Nomor 1 2016), 34.

16 Gesti Lestari, Fenomena Seksual di Kota Yogyakarta, (Fakultas IImu Sosial Universitas Negeri Yogyakarta (Skripsi), 2012), 25.

${ }^{17}$ Ibid. 
laki homoseksual tidak akan tertarik kepada seorang perempuan secantik dan semenarik apapun. Laki-laki homoseksual akan merasa nyaman, tenang, dan tentram ketika dia berada didekat sesama jenisnya yang dicintainya. D ia juga memiliki rasa cemburu, iri, dan bahkan benci kepada sesama jenisnya sendiri manakala teman sesama jenisnya mendekati dan bercinta dengan pacarnya (sesama jenisnya yaitu laki-laki)

\section{Biskssual}

Pengertian Biseksual secara kebahasaan dari kata "bi" yang artinya dua sedangkan "seksual" bermakna persetubuan antara lakilaki dan perempuan. ${ }^{18}$ Sehingga dapat disimpulkan secara Bahasa, bahwa Biseksual adalah orang yang tertarik kepada kedua jenis kelamin yaitu baik laki-laki ataupun perempuan. ${ }^{19}$

Misalkan seorang remaja pada masa perkembangannya terkadang mengalami fase kebingungan apakah dia tertarik pada orang yang berlainan gender (heteroseksual) atau tertarik pada orang yang memiliki gender yang sama (homoseksual) bahkan beberapa mengalami ketertarikan pada semua gender (biseksual).

Seorang pelaku biasanya menjalin hubungan asmara dalam kurun waktu tertentu dengan seseorang dari gender yang sama kemudian di waktu yang berlainan pelaku biseksual akan menjalin hubungan yang serius dengan seseorang dari gender yang berbeda. Maka orang seperti ini bisa dikategorikan sebagai pelaku biseksual.

Sementara remaja yang memiliki ketertarikan terhadap lawan jenis maupun sesama jenis bahkan keduanya biasanya masih dalam proses pengenalan diri akan orientasi seks sehingga belum bisa dikategorikan sebagai pelaku biseksual.

Transgender

${ }^{18}$ Peter Salim dan Yenny Salim, Kamus Bahasa Indonesia Kontemporer (Jakarta: Modern English Pers, 2002). Ed. Ketiga, 1355.

19 Departemen Pendidikan Nasional, Kamus Besar Bahasa Indonesia (Jakarta: PT Gramedia Pustaka, 2008), cet. Ke-1, ed. Ke-IV, 199. 
Secara etimologi transgender berasal dari dua kata yaitu "trans" yang berarti pindah (tangan; tanggungan); pemindahan ${ }^{20}$ dan "gender" yang berarti jenis kelamin ${ }^{21}$.

Istilah lain yang digunakan dalam operasi pergantian kelamin ialah "transseksual" yaitu merupakan terjemahan dari Bahasa Inggris. Disebut transseksual karena memang operasi tersebut sasaran utamanya adalah mengganti kelamin seorang waria yang menginginkan dirinya menjadi perempuan. ${ }^{22}$

Sedangkan secara terminologi transgender atau transseksual diartikan dengan suatu gejala ketidakpuasan seseorang karena merasa tidak adanya kecocokan antara bentuk fisik dan kelamin dengan kejiwaan, atau adanya ketidakpuasan dengan alat kelamin yang dimilikinya. Beberapa ekspresi yang dapat dilihat ialah bisa dalam bentuk dandanan (make up), gaya dan tingkah laku, bahkan sampai kepada operasi penggantian kelamin. ${ }^{23}$

\section{Penularan Virus LGBT di Masyarakat}

Kartini Kartono $^{24}$ mengemukakan banyak teori yang menjelaskan sebab-sebab homoseksual/ lesbian, antara lain:

a. Faktor herediter berupa ketidakseimbangan hormon-hormon seks.

b. Pengaruh lingkungan yang tidak baik/tidak menguntungkan bagi perkembangan kematangan seksual yang normal.

c. Seseorang selalu mencari kepuasan relasi homoseks/lesbian, karena ia pernah menghayati pengalaman homoseksual/ lesbian yang menggairahkan pada masa remaja. Salah satu contohnya :Seorang anak laki-laki pernah mengalami pengalaman traumatis dengan ibunya, sehingga timbul kebencian/ antipati

${ }^{20}$ Pius A. Partanto dan M. Dahlan Al Barry, Kamus Ilmiah Populer (Surabaya: Arkola, $\mathrm{tt}), 757$.

${ }^{21}$ Ibid., 197.

${ }^{22}$ Mahjuddin, Masailul Fiqhiyah Berbagai Kasus yang Dihadapi Hukum Islam Masa Kini (Jakarta: Kalam Mulia, 2005), 25.

${ }^{23} \mathrm{lbid}$.

${ }^{24}$ Kartini Kartono, Psikologi Abnormal dan Abnormalitas Seksual, (Bandung: CV. Mandar Maju, 1989), 248. 
terhadap ibunya dan semua wanita. Lalu muncul dorongan homoseksual yang jadi menetap.

Kemudian terdapat beberapa faktor yang menyebabkan seseorang itu cenderung untuk menjadi bagian dari LGBT diantaranya, yaitu: 1) Keluarga. Pengalaman atau trauma di masa anak-anak misalnya: Dikasari oleh ibu/ayah hingga si anak beranggapan semua pria/ perempuan bersikap kasar, bengis dan panas bara yang memungkinkan si anak merasa benci pada orang itu. Predominan dalam pemilihan identitas yaitu melalui hubungan kekeluargaan yang renggang. Bagi seorang lesbian misalnya, pengalaman atau trauma yang dirasakan oleh para wanita dari saat anak-anak akibat kekerasan yang dilakukan oleh para pria yaitu bapa, kakaknya maupun saudara laki-lakinya. Kekerasan yang dialami dari segi fisik, mental dan seksual itu membuat seorang wanita itu bersikap benci terhadap semua pria. ${ }^{25} \mathrm{Kedua}$, Pergaulan dan Lingkungan. Kebiasaan pergaulan dan lingkungan menjadi faktor terbesar menyumbang kepada kekacauan seksual ini yang mana salah seorang anggota keluarga tidak menunjukkan kasih sayang dan sikap orang tua yang merasakan penjelasan tentang seks adalah suatu yang tabu. ${ }^{26}$

Ketiga, Penyimpangan genetik. Seorang memiliki kecenderungan untuk melakukan homoseksual karena mendapat dorongan dari dalam tubuh yang sifatnya menurun/genetik. Penyimpangan faktor genetika dapat diterapi secara moral dan secara religius. ${ }^{27} \mathrm{Di}$ alam medis, pada dasarnya kromosom laki-laki normal adalah XY, sedangkan perempuan normal pula adalah XX. Bagi beberapa orang laki-laki itu memiliki genetik XXY. Dalam kondisi ini, laki-laki tersebut memiliki satu lagi kromosom $\mathrm{X}$

${ }^{25}$ Dr. Abu Ameenah Philips dan Dr.Zafar Khan, Islam dan Homoseksual (Jakarta: Pustaka Zahra, 2003), Cet.1, 85.

${ }^{26}$ Dr. Masyitah Ibrahim "Program Ikut Telunjuk Nafsu", Artikal diakses pada 20 May 2013, dari http:// www.utusan.com.my

27 Dra. Sri Habsari, Bimbingan dan Konseling SMA, diakses pada 24 May 2013 dari http:// books.google.co.id 
sebagai tambahan. Justru, perilakunya agak mirip dengan seorang perempuan. ${ }^{28}$

Keempat, Pengetahuan agama yang lemah. Minimnya pengetahuan dan pemahaman agama juga merupakan faktor internal yang mempengaruhi terjadinya homoseksual. Ini kerana peneliti merasakan didikan agama dan akhlak sangat penting dalam membentuk akal, pribadi dan pribadi individu itu. Pengetahuan agama memainkan peran yang penting sebagai benteng pertahanan yang paling ideal dalam mendidik diri sendiri untuk membedakan yang mana baik dan yang mana yang sebaliknya, haram dan halal dan lain-lain. ${ }^{29}$

\section{Pentingnya Pendidikan Seks pada Anak}

Pemahaman pendidikan seks di usia dini ini diharapkan anak agar anak dapat memperoleh informasi yang tepat mengenai seks. Hal ini dikarenakan adanya media lain yang dapat mengajari anak mengenai seks, yaitu media informasi. D engan mengajarkan pendidikan seks pada anak, diharapkan dapat menghindarkan anak dari risiko negatif perilaku seksual maupun perilaku menyimpang. Dengan sendirinya anak diharapkan akan tahu mengenai seksualitas dan akibatakibatnya bila dilakukan tanpa mematuhi aturan hukum, agama, dan adat istiadat, serta dampak penyakit yang bisa ditimbulkan dari penyimpangan tersebut.

Tingginya kasus kekeraan seksual pada anak (dild abuse) yang dilakukan orang-orang terdekat anak termasuk keluarga menunjukkan pentingnya pemahaman akan pendidikan seks usia dini. Masalah pendidikan seks kurang diperhatikan orang tua pada masa kini sehingga mereka menyerahkan semua pendidikan, termasuk pendidikan seks pada sekolah. Padahal, yang bertanggung jawab mengajarkan pendidikan seks di usia dini adalah orang tua, sedangkan sekolah hanya sebagai pelengkap dalam memberikan

${ }^{28}$ Dr. Syed Hassan, Kenapa Berlakunya Kecelaruan Jantina, (Jurnal al-Islâm: May 2011), 35.

29 Noor Azilawati Mohd Sabda, Siri Pemupukan Motivasi Insan, Menghindari Ancaman Seksual, (T. t: Pinang SDN.BHD), Cet.1, 16. 
informasi kepada si anak. Peranan orang tua, terutama ibu sangat strategis dalam mengenalkan pendidikan seks sejak dini kepada anak-anak mereka.

Secara umum pendidikan seks (sex education) dapat diartikan sebagai pendidikan tingkah laku yang baik, menjunjung tinggi nilainilai kemasyarakatan serta membantu seseorang menghadapi persoalan hidup yang berpusat pada naluri seks yang timbul dalam bentuk tertentu dan merupakan pengalaman manusia yang normal.

D ari pengertian tersebut dapat dipahami bahwa pendidikan seks bermaksud menerangkan semua hal yang berhubungan dengan seks dan seksualitas dalam bentuknya yang wajar, tidak terbatas pada anatomi, fisiologi, penyakit kelamin dan perilaku seks yang menyimpang. Tetapi yang terpenting adalah membentuk sikap serta kematangan emosional seseorang terhadap seks.

Sedangkan menurut Abdullah Nasih Ulwan, menyatakan bahwa pendidikan seks merupakan sebuah upaya pengajaran, penyadaran dan penerangan tentang masalah-masalah yang berkenaan dengan seks, naluri dan perkawinan. Sehingga jika anak telah tumbuh menjadi seorang pemuda dan dapat memahami urusan-urusan kehidupan, ia telah mengetahui masalah-masalah yang diharamkan dan yang dihalalkan bahkan mampu menerapkan. ${ }^{30}$

D engan demikian pendidikan seks adalah upaya orangtua dan pendidik lainnya untuk membiasakan perilaku positif yang berkaitan dengan seks, seperti memposisikan peran anak lakilaki dalam pikiran dan perilakunya sebagai anak laki-laki dan memposisi kan peran anak perempuan dalam pikiran dan perilakunya sebagai anak perempuan pula, menjauhkan anak-anak dari bacaan, gambar dan tontonan seks yang belum wajar dikonsumsi oleh anak, menjauhkan anak-anak dari kekerasan seksual, menyampaikan informasi positif tentang seks dan pernikahan yang sesuai dengan

30 Safrudin Azis, Pendidikan Seks Bagi Anak Berkebutuhan Khusus, Jurnal Kependidikan, Vol. II No. 2 Nopember 2014), 186. 
usia anak, serta hal-hal negatif yang berkaitan dengan seks sehingga menumbuhkan kesadaran pada anak tentang sex positif dan kapan anak berhak mengenalnya, agar anak-anak menghindari dan menjauhkan dirinya pergaulan bebas, anak-anak dapat menghindari seks negatif yang dilarang oleh norma-norma masyarakat dan agama.

Sedangkan menurut Suryadi, pendidikan seks merupakan usaha pemberian informasi kepada anak tentang kondisi fisiknya sebagai perempuan atau laki-laki dan kosekuensi psikologis yang berkaitan dengan kondisi tersebut. Secara umum, pendidikan seks terdiri atas penjelasan tentang organ reproduksi, kehamilan, tingkah laku seksual, alat kontrasepsi, kesuburan dan manepouse, serta penyakit kelamin. ${ }^{31}$

D emi menjaga kualitas diri anak agar terhindar dari perilaku homoseksual, berikut yang dapat kita lakukan:

1. Menegaskan Identitas Seksual Anak dan Membiasakannya Berperilaku sesuai Identitas.

Biasakanlah anak berperilaku sesuai identitas seksualnya, seperti anak perempuan main boneka. Pola asuh orang tua amat penting di sini. Sebagai sekolah pertama yang akan ditemui anak, keluarga, khususnya orang tua, hendaknya kita dapat menanamkan pendidikan seksual sejak dini. Bedakan perilaku pada anak laki-laki dan perempuan. Biasakan mereka untuk memiliki dan menyukai sesuatu hal yang sesuai jenis kelaminnya, misalnya boneka diberikan kepada anak perempuan, sedangkan mobil-mobilan diberikan kepada anak laki-laki. Ajarkan juga anak untuk memahami dientitas seksualnya untuk membiasakan mereka berperilaku sesuai seharusnya. Sebagai contoh, seorang anak perempuan diberi ketegasan bahwa ia berbeda dari anak laki-laki

${ }^{31}$ Endang Lestari, dkk., Peran Orang Tua Dalam M emberikan Pendidikan Seks Sedini Mungkin Di TK Mardisiswi Desa Kedondong Kecamatan Kebonsari Kabupaten Madiun. Nugroho, (Jurnal IImiah Pendidikan. Volume 02. Numbe 02, Nopember 2014), 125. 
sehingga pakaian dan cara berdandannya pun harus berbeda, jangan menyerupai.

2. Jangan Biasakan Anak Memperlihatkan Bagian Tubuh Tertentu di D epan Umum

3. Berikan pendidikan seksual sedini mungkin pada anak

Hal yang wajar ketika anak masih bayi, kita sebagai orang tua terbiasa mengganti bajunya dan membersihkan popoknya di depan umum. Namun, perlahan ketika anak makin dewasa, kita harus secara bijak dan sopan dalam menyentuh area pribadi anak. Mintalah izin ketika ingin mengganti pakaiannya, larang mereka ketika ingin buang air sembarangan atau tidak pada tempatnya, dan beri tahu bahwa mereka memiliki area pribadi yang tidak boleh dilihat dan disentuh orang lain, kecuali oleh diri mereka sendiri dan mungkin Ibunya ketika anak masih kecil. D engan cara ini, anak lambat laun akan memahami bahwa aurat yang ada di tubuh mereka adalah hal yang harus dijaga dengan baik.

4. Pisahkan Tempat Tidur Anak agar Mereka Mandiri dan Memahami Perbedaan G ender

Saat berusia 7 hingga 10 tahun, pisahkan tempat tidur anak agar ia mandiri dan memahami perbedaan gender. Perintah ini sejalan dengan isi hadis bahwa sebaiknya anak mulai diperintahkan salat dan tidur terpisah ketika berusia 7 hingga 10 tahun. Bahkan, kita berhak bersikap tegas pada mereka jika aturan main ini tidak dipenuhi. Sesekali, anak mungkin merengek untuk minta ditemani tidur oleh orang tua atau kakaknya, terlebih ketika sakit atau sedang manja. Siasati dengan memberi nasihat secara lembut bahwa kita akan menemaminya tidur kali itu saja karena anak harus belajar mandiri dan usianya sudah cukup dewasa untuk tidur terpisah.

5. Melindungi dan Menjauhkan Anak dari Berbagai Stimulus Perilaku Menyimpang

Jauhkan anak dari berbagai stimulus perilaku menyimpan. Nafsu adalah anugerah yang diberikan Allah kepada hamba-Nya, 
baik untuk makan, minum, maupun berhubungan seksual. D engan nafsu, manusia dapat bertahan hidup dan mempertahankan keturunannya. Tapi, pemenuhan yang tidak sesuai syariat tentu akan mendatangkan keburukan, baik di dunia maupun akhirat. Dengan makin merebaknya kasus homoseksual, tentu membuat paparan akan hal ini makin banyak, misalnya dari film, berita, hingga pembicaraan sehari-hari. Dampingi perkembangan anak agar kita dapat mengetahui kira-kira hal apa saja yang mereka lihat dan dengar sehari-hari dari lingkungannya. Berusahalah untuk jangan cuek dan terlalu membebaskan karena tuntutan zaman, tapi tetap beri anak kemudahan akses untuk bertanya kepada kita sebagai orang tua tentang masalah tersebut.

6. Perkuat Ilmu Agama Anak dan Ceritakan Kisah-Kisah Tuntunan, Khususnya tentang Nabi Luth

Perkuat anak dengan ilmu agama sejak dini dan ceritakan kisah-kisah islami. Agama adalah pondasi penting dalam membentuk karakter anak. Menjadi contoh bagi mereka adalah langkah awal dalam mendidik. Dalam kehidupan sehari-hari, ajarkan ilmu agama dalam setiap sendi dan kegiatan. Sering-sering menceritakan kisah keagamaan, seperti kisah nabi dan para sahabat. Berkaitan dengan kasus ini, cerita yang paling cocok adalah kisah Nabi Luth. ${ }^{32}$

\section{Kesimpulan}

LBGT adalah singkatan dari Lesbian, Biseksual, $\mathrm{G}$ ay, dan Transgender. Homoseksual atau $G$ ay adalah suatu perilaku seks antara laki-laki dengan laki-laki atau antara sesama jenis laki-laki, Lesbian adalah ketertarikan perempuan kepada perempuan, Biseksual adalah ketertarikan seseorang pada dua jenis kelamin sekaligus, baik kepada perempuan maupun kepada laki-laki, dan

32 http://abiummi.com/5-hal-yang-harus-ditanamkan-agar-anak-terhindar-dariperilaku-homoseksual/, (12 April 2018) 
Transgender adalah pergantian jenis kelamin dan rekonstruksi pada jenis kelamin yang lain

selain dirinya.

Pendidikan seks adalah upaya orangtua dan pendidik lainnya untuk membiasakan perilaku positif yang berkaitan dengan seks, seperti memposisikan peran anak laki-laki dalam pikiran dan perilakunya sebagai anak laki-laki dan memposisi kan peran anak perempuan dalam pikiran dan perilakunya sebagai anak perempuan pula, menjauhkan anak-anak dari bacaan, gambar dan tontonan seks yang belum wajar dikonsumsi oleh anak, menjauhkan anakanak dari kekerasan seksual, menyampaikan informasi positif tentang seks dan pernikahan yang sesuai dengan usia anak, serta hal-hal negatif yang berkaitan dengan seks sehingga menumbuhkan kesadaran pada anak tentang sex positif dan kapan anak berhak mengenalnya, agar anak-anak menghindari dan menjauhkan dirinya pergaulan bebas, anak-anak dapat menghindari seks negatif yang dilarang oleh norma-norma masyarakat dan agama. 


\section{DAFTAR PUSTAKA}

Yatimin, Etika Seksual dan Penjimpangannya dalam Isam (Jakarta: Amzah,2003)

Maramis W. F., Catatan Ilmu Keedkteran Jiva, , (Surabaya: Airlangga University Press 2004)

Sinyo, AnakkuBertanya Tentang LGBT,(jakarta:PT Elex Media Komputindo, 2014)

Kartini Kartono, Psikdog Abnomal dan Abnomalitas Saksual, (Bandung: CV. Mandar Maju, 1989)

K ams Besar Bahasa Indonesia, (Jakarta: Balai Pustaka, 2002)

Heru Kasida Brataatmaja, Kams Bahasa Indonesia, (Y ogyakarta.Penerbit Kanisius, 1994)

Muhammad Mahmud Nasution, Fenomena LBGT Dalam Perspaktif HukumIsam (Jurnal al-Maqasid Volume 2 Nomor 12016 )

Gesti Lestari, Fenomena Seksual di Kda Yogjakarta, (Fakultas Ilmu Sosial Universitas Negeri Y ogyakarta (Skripsi), 2012)

Peter Salim dan Y enny Salim, Kams Bahasa Indonesia Kontemparer (Jakarta: Modern English Pers, 2002). Ed. Ketiga.

D epartemen Pendidikan Nasional, Kams Besar Bahasa Indonesia (Jakarta: PT G ramedia Pustaka, 2008)

Pius A. Partanto dan M. D ahlan Al Barry, Kams Ilmiah Populer (Surabaya: Arkola, $\mathrm{tt}$ )

Mahjuddin, Masailul Fiqhiyah Berbagai Kasus yang Dihadapi Hukum IslamMasa Kini (Jakarta: Kalam Mulia, 2005)

Dr. Abu Ameenah Philips dan Dr.Zafar Khan, Isam dan Homosksual, Cet.I (Jakarta: Pustaka Zahra, 2003)

D r. Syed Hassan, Kenapa Belakunya Keedanuan Jantima, (Jurnal alIslâm: May 2011)

Noor Azilawati Mohd Sabda, Sin Pempukan Motivasi Insan, Menghindari Ancaman Seksual, (T. t: Pinang SD N.BHD).

Safrudin Azis, Pendidikan Seks Baġ Anak Berkebutuhan Khusus, (Jurnal Kependidikan, Vol. II No. 2 Nopember 2014) 
Endang Lestari, dkk., Peran OrangTua DalamMemberikan Pendidikan Seks Sedini Mungkin Di TK Mardisiswi Desa Keelondang Kecamatan Kebonsari Kabupaten Madiun Nugroh, (Jurnal Ilmiah Pendidikan. Volume 02. Numbe 02, Nopember 2014)

http:/ / abiummi.com/ 5-hal-yang-harus-ditanamkan-agar-anakterhindar-dari-perilaku-homoseksual/ , (12 April 2018)

https:/ / www.jawapos.com/ read/ 2017/ 12/ 24/ 177083/ lgbtmakin-marak-di-kalangan-anak-pakar-al-azhar-sarankan-ini, (11 A pril 2018).

www.narth.com, Jupiter D an, 2002, Runtuhnya Teøi “GayGene”. 